\title{
Using Nested-PCR for Detection of Avian Influenza Virus
}

\author{
S.P. BELADI ${ }^{1}$, S.A. GHORASHI ${ }^{2}$, D. MORSHEDI ${ }^{2}$ \\ ${ }^{1}$-School of Veterinary Medicine, Islamic Azad University, Karaj, Iran \\ 2-National Institute of Genetic Engineering and Biotechnology, Tehran, Iran \\ Received August 26, 2004 \\ Accepted November 10, 2005
}

\begin{abstract}
Beladi S.P., S.A. Ghorashi, D. Morshedi: Using Nested-PCR for Detection of Avian Influenza Virus. Acta Vet Brno 2005, 74: 581-584.

Avian influenza virus can infect all poultry species. Infection of Broilers and layers with this virus can cause heavy economic loss to poultry industry annually. In this study a RT-PCR was optimized to detect avian influenza virus, regardless of its subtype. A part of matrix gene which is conserved among avian influenza viruses was amplified. The PCR product was cloned in $\mathrm{pTZ}$ 57R/T vector and sequenced. The sequence data confirmed the specificity of the test. The sensitivity of PCR was determined to be $3 \times 10^{-2} \mathrm{EID}_{50} / \mathrm{ml}$. Using internal primers, a nested-PCR was carried out and the sensitivity was increased to $3 \times 10^{-4} \mathrm{EID}_{50} / \mathrm{ml}$. Due to high sensitivity of the test for detection of avian influenza viruses, this technique can be used as a robust diagnostic method for detection of avian influenza virus.
\end{abstract}

Avian influenza virus, PCR

Influenza viruses are of three types $\mathrm{A}, \mathrm{B}$ and $\mathrm{C}$. The typing is based on antigenic differences on the nuclear and matrix proteins of the virus (Poddar 2002). Avian influenza (AI) is a viral disease spread worldwide and is caused by influenza A viruses of the family Orthomyxoviridae. Influenza A viruses are classified into subtypes on the basis of two surface glycoproteins: haemagglutinine (HA) and neuraminidase (NA). These two proteins are highly variable, therefore, a great number of AI virus subtypes occur. In AI viruses, 15 antigenically different HA and 9 antigenically different NA glycoproteins are recognized (Starick et al. 2000). In each subtype, a range of nonpathogenic to highly pathogenic strains may be present. Although most AI viruses in chickens cause mild and localized infections of the respiratory and intestinal tracts, highly pathogenic strains become dispersed throughout the body and produce an acute, systemic, and often fatal disease (Wood et al. 1996; Senne et al. 1996). Among AI viruses, only $\mathrm{H} 5$ and $\mathrm{H} 7$ subtypes are particularly important because they are known to be highly pathogenic (Bosch et al. 1979; Senne et al. 1996). The control of influenza transmission in chickens is dependent upon immunizations, the rapid identification of cases, movement control, culling infected birds and strict disinfection. Avian influenza (AI) is diagnosed by virus isolation or by serological methods. The standard laboratory method for diagnosis of influenza is based on isolation and characterization of the virus (Harm on 1992). However, the virus isolation is a tedious and time-consuming technique. Immunofluorescence assay (IFA) and enzyme-linked immunosorbent assay (ELISA), have been applied for rapid detection of influenza infection (Rein et al. 1996). However, antibodies against AI virus may not be detectable in less than 7 - 14 days after virus exposure. In addition, in countries like Iran where mass immunization of birds with inactivated vaccine is practiced, using serological methods may not be practical. The polymerase chain reaction (PCR) is an alternative rapid detection method of the virus and is more sensitive than standard virus

Address for correspondence:

Seyed Ali Ghorashi

Department of Microbiology

National Institute of Genetic Engineering and Biotechnology

P.O. BOX 14155-6343, Tehran, Iran
Phone: (+98) 214580386

Fax: (+98) 214580399

E-mail: alig@nrcgeb.ac.ir

http://www.vfu.cz/acta-vet/actavet.htm 
isolation (Cherian et al. 1994). Also the sensitivity and specificity of detection by PCR is higher compared with the other available method mentioned above (Atmar et al. 1996). For this reason, but also in order to improve diagnosis of avian influenza, reverse transcriptase PCR (RT - PCR) assay is considered to be a helpful tool (W ood et al. 1993; Senne et al. 1996; Banks et al. 1998). The objective of this study is to optimize a rapid, sensitive and specific RT-PCR and nested-PCR assay for detection of all strain variants of avian influenza viruses regardless of haemagglutinin and neuraminidase subtypes.

\section{Materials and Methods}

Virus strain

A prototype influenza virus type A (H9N2) was provided by the Razi Institute (Karaj, Iran). The virus was propagated in embryonating chicken eggs via the allantoic sac, had a titer of $10^{8} \mathrm{EID}_{50} / \mathrm{ml}$.

RNA extraction

Viral RNA from allantoic-amniotic fluid was extracted using phenol-thiocyonate based method (Chomczynski and Sacci 1987). Briefly, $1 \mathrm{ml}$ of RNA extraction solution was added to $0.3 \mathrm{ml}$ of virus suspension sample in a $1.5 \mathrm{ml}$ microfuge tube. This was followed by $0.2 \mathrm{ml}$ chloroform extraction and precipitation of supernatant by adding equal volume of cold isopropanol and subsequent centrifugation at $10000 \mathrm{rpm}$ for 15 minutes. Thereafter, the resulting pellet was washed with $70 \%$ ethanol, dried and resuspended in $20 \mu \mathrm{l}$ of DEPC- $\mathrm{dH}_{2} \mathrm{O}$. Extracted RNA was immediately used or stored at $-70{ }^{\circ} \mathrm{C}$ until needed.

Reverse transcriptase-polymerase chain reaction (RT-PCR)

Oligonucleotide primers for RT reaction and subsequent PCR amplification were chosen from matrix gene of virus genome as previously published (Starick et al. 2000). The sequence of oligonucleotide primers are IVAM1 (5'-AGCGTAGACGCTTTGTC-3') and IVA-M2 (5'-GACGATCAAGAATCCAC-3'). For cDNA synthesis, $4 \mu \mathrm{l}$ of extracted RNA, $0.25 \mu \mathrm{g}$ of reverse primer and $5 \mu \mathrm{l}$ of DEPC- $\mathrm{dH}_{2} \mathrm{O}$ was denatured at $70{ }^{\circ} \mathrm{C}$ for $5 \mathrm{~min}$ and cooled on ice. The following was added to the reaction, $8 \mu 1 \mathrm{RT}$ buffer $(5 \mathrm{X}), 1 \mu 1(10 \mathrm{mM}) \mathrm{dNTP}, 2$ $\mu 1 \mathrm{RNase}$ inhibitor $(40 \mathrm{U})$ and incubated at $37^{\circ} \mathrm{C}$ for $5 \mathrm{~min}$. Finally $40 \mathrm{U}$ reverse transcriptase (M-mulv) and $\mathrm{DEPC}-\mathrm{dH}_{2} \mathrm{O}$ to give a final reaction volume of $40 \mu 1$ was added and mixture was further incubated at $37^{\circ} \mathrm{C}$ for $60 \mathrm{~min}$ followed by $70{ }^{\circ} \mathrm{C}$ for $10 \mathrm{~min}$. PCR amplification of cDNA was carried out in a total volume of $50 \mu 1$ containing $5 \mu \mathrm{l} \mathrm{cDNA}, 5 \mu \mathrm{l}$ of $10 \mathrm{X}$ PCR buffer, $0.25 \mu \mathrm{g}$ of each forward and reverse primer, $1.5 \mathrm{mM} \mathrm{MgCl} 2,1$ $\mu 1$ of dNTP $(10 \mathrm{mM}), 1$ unite of Taq DNA polymerase and $\mathrm{dH}_{2} \mathrm{O}$ to the final volume of reaction. The mixture was overlaid with $30 \mu 1$ of mineral oil and subjected to the following programme using a thermocycler: $94^{\circ} \mathrm{C}$ for $3 \mathrm{~min}(1 \mathrm{cycle}), 94^{\circ} \mathrm{C} 30 \mathrm{sec}, 58^{\circ} \mathrm{C} 30 \mathrm{sec}, 72{ }^{\circ} \mathrm{C} 30 \mathrm{sec}(30 \mathrm{cycles})$ and $72{ }^{\circ} \mathrm{C} 10 \mathrm{~min}(1 \mathrm{cycle})$. Results were observed after $7 \mu 1$ of PCR product was mixed with $2 \mu 1$ of gel loading buffer and visualized after electrophoresis on an ethidium bromide stained 1\% agarose gel using a UV transilluminator.

Sequencing the PCR products

The PCR product was cloned into a T-vector (pTZ57R) based on manufacturer's instructions. Recombinant plasmids were sequenced and data were compared to that of the AIV strain using the DNASTAR program package.

Sensitivity of the RT-PCR

To determine the sensitivity of PCR, 10 fold dilutions of virus stock $\left(10^{8} \mathrm{EID}_{50}\right.$ to $\left.10^{-5} \mathrm{EID}_{50} / \mathrm{ml}\right)$ were prepared in $\mathrm{dH}_{2} \mathrm{O}$. RNA was extracted from diluted virus suspensions and was examined in RT-PCR.

Nested-PCR

Nested primers were selected from the PCR sequence and second round of PCR was carried out. Oligonucleotides AIV-N-F (5'-ATA TAC AAC CGG ATG GGG ACA-3') and AIV-N-R (5'-CCT AGC CTG ACT TGC GAC TTC-3') were designed for nested-PCR amplification. In nested-PCR $1 \mu$ lof first round PCR was used as template DNA and annealing temperature was increased to $58^{\circ} \mathrm{C}$. The rest of materials and procedure were similar to the PCR protocol as described above.

Sensitivity of nested-PCR

Each amplicon of first round PCR from 10 fold dilutions of virus stock were tested in the second round PCR. Seven microliter of PCR and nested-PCR products was separately examined by agarose gel electrophoresis.

\section{Results}

A highly conserved region within the matrix gene of avian influenza virus was amplified and a single DNA fragment of $600 \mathrm{bp}$ was observed while no DNA bands were produced in negative control sample (data not shown). 
Specificity of the RT-PCR

The nucleotide sequence for PCR amplicon was determined by direct sequencing (Fig.1). Results were compared with the published sequence of the matrix gene of avian influenza virus. The two sequences were found identical.

AGCGTAGACGCTTTGTTCAAAATGCCCTTAATGGAAATGGGGATCCAAACA ACATGGATAGAGCAGTCAAACTGTACAGGAAGCTAAAAAGGGAAATAACA TTCCATGGGGCAAAAGAAGTTGCACTTAGTTATTCAACTGGTGCACTTGCC AGTTGCATGGGCCTCATATACAACAGAATGGGGACTGTGACCACCGAAGTG GCATTTGGCCTGGTATGCGCCACATGTGAGCAGATTGCTGACTCCCAGCAT CGGTCTCACAGGCAAATGGTGACAATAACAAACCCACTGATCAGACATGA GAACAGAATGGTACTGGCTAGTACTACGGCTAAAGCCATGGAGCAAATGG CAGGATCAAGTGAGCAGGCAGCAGAGGCTATGGAGGTTGCTATTCAGGCT AGACAGATGGTGCAGGCAATGAGGACCATTGGAACTCATCCTAGCACCAGT GCTGGTCTAAAAGATGATCTCCTTGAAAATTTGCAGGCCTACCAGAAACGG ATGGGAGTGCAAATGCAGCGATTCAAGTGATCCTCTCGTTATTGCAGCAAG TATCATTGGGATCTTGCACTTGATATTGTGGATTCTTGATCGTC

Fig. 1. Nucleotide sequence of PCR product ( $600 \mathrm{bp})$, a part of AIV matrix gene

\section{Sensitivity of the RT-PCR}

Serial 10 fold dilutions from the virus stock with a titer of $3 \times 10^{9} \mathrm{EID}_{50} / \mathrm{ml}$ were prepared and RNA extraction followed by RT-PCR was carried out. Positive DNA bands of expected size were detected in ethidium bromide stained agarose gel covering a range from $3 \times 10^{8}$ to $3 \times 10^{-2} \mathrm{EID}_{50} / \mathrm{ml}$. No signal was observed when RNA extracted from samples with lower dilutions or negative control (Plate VIII, Fig. 2).

Sensitivity of Nested-PCR

Each PCR product from 10 fold dilutions of virus stock was tested in nested-PCR. A 240 bp DNA fragment was observed in $3 \times 10^{8}$ to $3 \times 10^{-4} \mathrm{EID}_{50} / \mathrm{ml}$ samples. DNA was not amplified from lower dilutions or from PCR and nested-PCR negative controls. Nested-PCR was found to be 100 times more sensitive than PCR since the viral genome was detectable in samples with lower dilutions (Plate VIII, Fig. 3).

\section{Discussion}

Some strains of avian influenza A virus are lethal to poultry, while majority of field isolates are nonlethal. Due to economic impact of influenza infection on poultry industry, rapid diagnosis of causative agent is important in control of virus transmission to other poultry farms (Horimoto and Kaw a oka 1995). Influenza infection is diagnosed by virus isolation and identification or serological tests. However, virus isolation and identification is tedious and time consuming and serological tests are less practical since mass vaccination is practiced. The RT-PCR assay is a sensitive and specific method that can detect influenza virus in a shorter time (Reina et al. 1996; Atmar et al. 1996). Using primers selected from a highly conserved region of the matrix protein coding gene of AIV, it was possible to amplify an expected size of the matrix gene of virus RNA in RT-PCR assay. The sequence analysis of PCR product indicated that a part of AIV matrix gene has been amplified. Therefore, the assay was found to be specific for screening of AIV genome in the sample. Since primer pairs used in the PCR were chosen from a conserved region of the matrix gene of AIV genome, the assay is expected to detect influenza A virus RNA regardless of virus subtypes. The sensitivity of PCR was determined to be $10^{-2} \mathrm{EID}_{50} / \mathrm{ml}$. This sensitivity might be good enough for the detection of AIV genome in the clinical samples. However, the detection limit of nested-PCR was found to be $10^{-4} \mathrm{EID}_{50} / \mathrm{ml}$ which is 100 fold more 
sensitive than PCR. This specific RT-PCR for detection of avian influenza virus can be used as a diagnostic tool in complement with other procedures. Confirmation of diagnosis of influenza infections would be also possible. This assay is superior to conventional techniques because viral RNA can be directly detected in clinical tissue samples in less than six hours, therefore, it is less time consuming compared to other diagnostic methods.

\section{Využití metody Nested-PCR pro detekci viru ptačí chřipky}

Virus ptačí chřipky může infikovat všechny druhy drůbeže. Infekce brojlerů a snáškových linií tímto virem může způsobovat drůbežářskému průmyslu každoročně velké ekonomické ztráty. V této studii bylo optimalizováno RT-PCR pro detekci viru ptačí chřipky nezávisle na jeho subtypu. Byla amplifikována část genu matrix, která je pro viry ptačí chřipky společná. Produkt PCR byl klonován a sekvenován ve vektoru pTZ57R/T. Data sekvence potvrdila specificitu testu. Senzitivita testu byla stanovena jako $3 \times 10^{-2}$ EID $_{50} \mu \mathrm{m} \cdot 1^{-1}$. Při provedení nested-PCR s využitím interních primerů vzrostla senzitivita na $3 \times 10^{-4} \mathrm{EID}_{50} \mu \mathrm{m} \cdot \mathrm{l}^{-1}$. Vzhledem $\mathrm{k}$ vysoké senzitivitě techniky by mohl být tento test využíván jako spolehlivá metoda detekce viru ptačí chřipky.

\section{Acknowledgement}

Authors wish to thank Dr. Reza Toroghi from Razi Institute for providing virus samples.

\section{References}

ATMAR RL, BAXTER BD, DOMINGUEZ EA, TABER LH 1996: Comparison of reverse transcription-PCR with tissue culture and other rapid diagnostic assays for detection of type A influenza virus. J Clin Microbiol 34: $2604-2606$

BANKS J, SPEIDEL E, ALEXANDER DJ 1998: Characterization of an avian influenza A virus isolated from a human- is an intermediate host necessary for the emergence of pandemic influenza viruses? Arch Virol 143: 781-787

BOSCH FX, ORLICH M, KLENK HD, ROTT R 1979: The structure of the haemagglutinine, a determinant for the pathogenicity of influenza viruses. Virology 95: 197-207

CHERIAN T, BOBO L, STEINHOFF MC, KARRON RA, YOLKEN RH 1994: Use of PCR-enzyme immunoassay for identification of influenza A virus matrix RNA in clinical samples negative for cultivable virus. J Clin Microbiol 32: 623-628

CHOMCZYNSKI PY, SACCI N 1987: Single-step method of RNA isolation by acid guanidine thiocyanatephenol-chloroform extraction. Anal Biochem 162: 156-159

HARMON MW 1992: Influenza viruses. In: LENNETTE EH (Ed.): Laboratory Diagnosis of Viral Infections. Second ed. Marcel Dekker, New York, pp. 515-534

HORIMOTO T, KAWAOKA Y 1995: Direct reverse transcriptase PCR to determine virulence potential of influenza A viruses in birds. J Clin Microbiol 33: 748-750

PODDAR SK 2000: Influenza virus types and subtypes detection by single step single tube multiplex reverse transcription-polymerase chain reaction (RT-PCR) and agarose gel electrophoresis. J Virol Meth 99: 63-70

REINA J, MUNAR M, BLANCO I 1996: Evaluation of a direct immunofluorescence assay, dot-blot enzyme Immunoassay, and shell vial culture in the diagnosis of lower respiratory tract infections caused by influenza A virus. Diagn Microbiol Infect Dis 25: 143-145

SENNE DA, PANIGRAHY B, KAWAOKA Y, PEARSON JE, SUSS J, LIPKIND M, KIDA H, WEBSTER RG 1996: Survey of the haemagglutinin (HA) cleavage site sequence of $\mathrm{H} 5$ and $\mathrm{H} 7$ avian influenza viruses: amino acid sequence at the HA cleavage site as a marker of pathogenicity potential. Avian Dis 40: 425-437

STARICK E, ROMER-OBERDORFER A, WERNER O 2000: Type and subtype-specific RT-PCR assay for avian influenza A viruses (AIV). J Vet Med B 47: 295-301

WOOD GW, BANKS J, STRONG I, PARSONS G, ALEXANDER DJ 1996: An avian influenza virus of H10 subtype that is highly pathogenic for chickens, but lacks multiple basic amino acids at the haemagglutinin cleavage site. Avian Pathol 25: 799-806

WOOD GW, MCCAULEY JW, BASHIRUDDIN JB, ALEXANDER DJ 1993: Deduced amino acid sequences at the haemagglutinin cleavage site of avian influenza A viruses of the $\mathrm{H} 5$ and $\mathrm{H} 7$ subtypes. Arch Virol 130: 209-217 
Plate VIII

Beladi S. P. et al.: Using Nested-PCR ... pp. 581-584

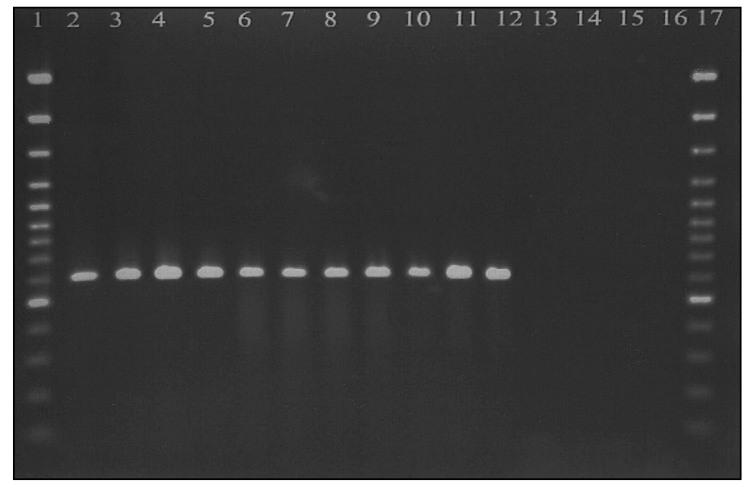

Fig. 2. The PCR Products of AIV RNA extracted from 10 fold serial dilutions of virus. lane 1 and 17: DNA size marker, ladder 100. lane 2 - 15: correspond to $3 \times 10^{8}, 3 \times 10^{7}, 3 \times 10^{6}, 3 \times 10^{5}$, $3 \times 10^{4}, 3 \times 10^{3}, 3 \times 10^{2}, 3 \times 10^{1}, 3,3 \times 10^{-1}, 3 \times 10^{-2}, 3 \times 10^{-3}, 3 \times 10^{-4}, 3 \times 10^{-5} \mathrm{EID}_{50} / \mathrm{ml}$ respectively. lane 16: negative control

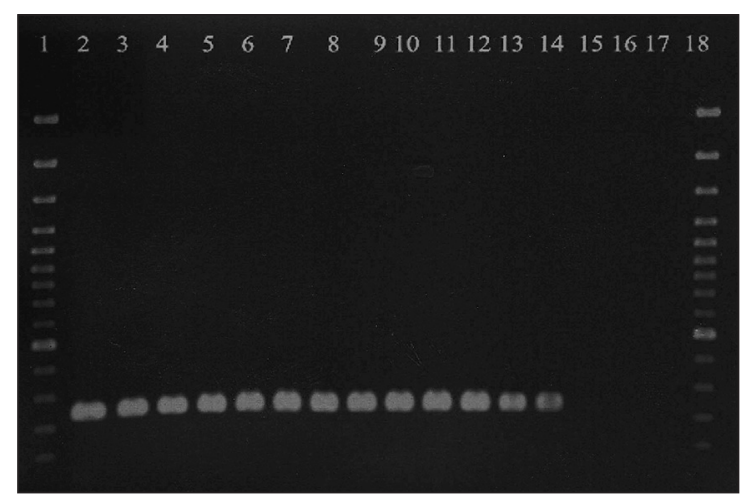

Fig. 3. The sensitivity of nested-PCR for detection of AIV genome in 10 fold serial dilution samples. lane 1 and 18: DNA size marker, ladder 100. lane 2 - 15: correspond to $3 \times 10^{8}, 3 \times 10^{7}, 3 \times 10^{6}$, $3 \times 10^{5}, 3 \times 10^{4}, 3 \times 10^{3}, 3 \times 10^{2}, 3 \times 10^{1}, 3,3 \times 10^{-1}, 3 \times 10^{-2}, 3 \times 10^{-3}, 3 \times 10^{-4}, 3 \times 10^{-5}, \mathrm{EID}_{50} / \mathrm{ml}$ dilutions of the virus respectively. lane 16: PCR negative control. lane 17: nested-PCR negative control 